\title{
Congressional Capitulation: War Power and the United States Congress
}

\author{
Ryan M. Yonk ${ }^{1}$ \\ ${ }^{1}$ Department of Economics and Finance, Utah State University, Logan Ut, USA \\ Correspondence: Ryan M. Yonk, 3565 Old Main Hill, Logan Utah 84322, USA. E-mail: ryan.yonk@usu.edu
}

Received: July 29, 2016 Accepted: September 26, 2016 Online Published: October 30, 2016

doi:10.5539/jpl.v9n9p172 URL: http://dx.doi.org/10.5539/jpl.v9n9p172

\begin{abstract}
The question of who should utilize the war power has been debated from the founding of the republic and the core issues while couched in different terms, and while war has become much more technologically advanced, remain the same. The fundamental question is one of what the President can do, and what Congress should do. I attempt to primarily address the question of what Congress should do with regard to the war powers rather than what the President can do because the scope of presidential war powers has been extensively researched and written about in the scholarly literature. Instead I address what from an institutional structure and policy perspective Congress ought to do with relation to the war powers and their execution.
\end{abstract}

Keywords: president, war powers resolution, congress

\section{Introduction}

"We have already given in example one effectual check to the dog of war by transferring the power of letting him loose from the Executive to the Legislative body..."

Thomas Jefferson: (Letter to Madison, 1789.) $)^{l}$

Presidential War Power has a long history as an implicit power of the executive granted by the U.S. constitution. It has been lauded as a fundamental power, which provides for a vigorous executive who can actively govern, engage in foreign policy, and provide for the common defense of the union. This view while widely held even by members of congress provides an incomplete picture of both of what the war powers of each branch are and how the framers envisioned their use. Like nearly all of the powers granted to individual branches by the constitutional order, war power as originally conceived was designed to provide for significant checks and balances between branches.

The question of who should utilize the war power has been debated from the founding of the republic and the core issues while couched in different terms, and while war has become much more technologically advanced, remain the same.

The fundamental question is one of what the President can do, and what Congress should do. In what follows I attempt primarily to address the question of what Congress should do with regard to the war powers rather than what the President can do because the scope of presidential war powers has been extensively researched and written about in the scholarly literature. Instead the institutional structure and policy options that Congress ought to use with relation to the war powers and their execution, and impediments to their use. I begin with an examination of what the constitutional underpinnings of the Congressional War power are, how congress has used them, how congress has responded to vigorous presidential war powers, and why congress seems reluctant to utilize those powers granted them.

\subsection{Constitutional Underpinnings}

The most appropriate place to begin any serious discussion of War Powers and specifically Congressional war power is with what powers the constitutional order delegates specifically. The powers granted to the congress by Article One Section 8 provide a compelling argument for vigorous congressional use of the war power.

"The Congress shall have power... To declare War"

${ }^{1}$ Jefferson, Thomas. Letter to James Madison 6 Sept. 1789. 


\section{(U.S. Constitution, 1787)}

When considering the war powers of Congress, these are the words of the Constitution that most readily come to mind, and if they were the only powers mentioned and specifically deeded to Congress their power would remain significant. The ability to declare war was given to congress specifically to prevent the executive from unilateral action, which would engage the United States in open hostilities, as had been the prerogative of the British monarch.

The initial draft of the Constitution had included language providing congress the power to "make war" rather than the final language, which appears to cede some power. (Ketchum 1986) This distinction was debated in detail by those at the convention was altered to provide actual power to the President acting as Commander-in-chief of the military in times of war. In Federalist 74, Alexander Hamilton provides an explanation for the necessity of a vigorous commander in chief. "The direction of war implies the direction of the common strength; and the power of directing and employing the common strength forms a usual and essential part in the definition of the executive authority." (Rossiter et al, 1999) The change in verbiage while significant cannot be construed to imbue the executive with the singular prerogative to utilize the war powers. Instead it represents recognition of the necessity of direction by a single leader after the decision to utilize the war powers has been made by those with the power to declare war, namely the Congress.

However, the powers given to congress with relation to war power are not limited merely to a single phrase. The Constitution continues and lays out specific powers that are the exclusive prerogative of Congress.

$$
\begin{aligned}
& \text { "[To] ... grant Letters of Marque and Reprisal, and make Rules concerning Captures on Land and } \\
& \text { Water; } \\
& \text { To raise and support Armies, but no Appropriation of Money to that Use shall be for a longer Term } \\
& \text { than two Years; } \\
& \text { To provide and maintain a Navy; } \\
& \text { To make Rules for the Government and Regulation of the land and naval Forces; } \\
& \text { To provide for calling forth the Militia to execute the Laws of the Union, } \\
& \text { suppress Insurrections and repel Invasions; }
\end{aligned}
$$

To provide for organizing, arming, and disciplining the Militia, and for governing such Part of them as may be employed in the Service of the United States, reserving to the States respectively, the Appointment of the Officers, and the Authority of training the Militia according to the discipline prescribed by Congress;" (U.S. Constutution 1787)

The delegated authority found in the much less referenced part of Article One Section Eight contains significant war powers. These powers of the purse, organization, and the now arcane ability of congress to authorize private groups to enter into armed conflict provide important vehicles for congress to utilize its portion of the war power.

The ability of Congress to create and organize both the Navy, and Militia imply and inherent connection both to the war power and to the armed forces. Rather than armed forces being the exclusive province of the President, Congress is empowered to create, regulate, oversee, and utilize them with the President acting as the Commander-in-Chief. The inherent powers of the executive regarding the military and war are well balanced by the explicit powers granted to congress by Article 1 Section 8 . These powers given to Congress by the founders represent important possibly essential duties of the legislative branch.

The war power granted to Congress by the U.S. Constitution solely authorizes it to declare war, to appropriate money for war, to organize armed forces for the nation, to govern and regulate those forces once organized. These powers suggest a vigorous role for legislative branch in determining the state of war and peace, and seem to require that they be actively involved in the decisions, which would lead a nation to war. These powers are held exclusively by Congress, and as such Congress under the Constitutional order must bear the responsibility of their use. The rationale of the founders to provide power in such a way is easy to see, war power had been one of the most misused powers of the Monarch.

\section{The Use of the War Powers}

The use of these war powers by Congress has been manifest in two main ways; the traditional declaration of war, and Resolutions authorizing force. The Traditional Declaration of War has been used only infrequently by the Congress in the two hundred odd years since the convention. The six instances of the use of the formal declaration of war are provided below. 
Table 1. Declarations of war by the United States 1787-1994

\begin{tabular}{ccc}
\hline Date & War & Antagonist(s) \\
\hline June 18,1812 & War of 1812 & United Kingdom \\
May 13,1846 & Mexican War & The Republic of Mexico \\
April 24, 1898 & Spanish-American War & Spain \\
April 6, 1917 & World War I & Germany \\
& & Austro-Hungarian Empire \\
December 8,-11 1941 & World War II & Japan, Germany, Italy \\
(June 5, 1942) & & (Bulgaria, Hungary, \\
January 12,1991 & Persian Gulf War ${ }^{3}$ & Romania) \\
& & Iraq \\
\hline
\end{tabular}

The question then must be asked were these reasoned congressional actions where the use of the war power independently used by congress. The short answer is no. In each of the above cases the declaration of war was requested by the President and the wording of the declarations are illustrative of the failure of Congress to utilize their war power outside of a request by the President.

War of 1812

"Be it enacted by the Senate and House of Representatives of the United States of America in Congress assembled, That war be and the same is hereby declared to exist between the United Kingdom of Great Britain and Ireland and the dependencies thereof, and the United States of America and their territories; and that the President of the United States is hereby authorized to use the whole land and naval force of the United States to carry the same into effect, and to issue to private armed vessels of the United States commissions or letters of marque and general reprisal, in such form as he shall think proper, and under the seal of the United States, against the vessels, goods, and effects of the government of the said United Kingdom of Great Britain and Ireland, and the subjects thereof APPROVED, June 18, 1812" (An Act Declaring War, 1812)

The Resolution authorizing war against Great Britain is the first actual declaration of war under the constitution of 1787, and set out a pattern for others to follow, authorizing the president to utilize the powers granted congress under Article 1 Section 8. This pattern of delegating specific powers from the congressional cadre forms the basis of each of the future declarations. Congressional delegation of powers has become common place and begs the question, is delegation of power actually using that power? Is merely allowing the executive to utilize the powers granted congress the purpose the founders had in mind when they granted specific powers to congress. A reading of the Notes from the Convention and the Federalist papers reveals no such specific intent, and no prohibition.

\section{Spanish-American War}

"Be it enacted by the Senate and House of Representatives of the United States of America in Congress assembled, First. That war be, and the same is hereby, declared to exist, and that war has existed since the 21st day of April, A. D. 1898, including said day, between the United States of America and the Kingdom of Spain.

Second. That the President of the United States be, and he hereby is, directed and empowered to use the entire land and naval forces of the United States and to call into the actual service of the United States the militia of the several States to such extent as may be necessary to carry this act into effect.

Approved, April 25, 1898." (An Act Declaring That War, 1898)

World War II - Japan

"Whereas the Imperial Government of Japan has committed unprovoked acts of war against the Government and the people of the United States of America: Therefore be it Resolved by the Senate

\footnotetext{
2 Inforamtion adapted from: Regens, James, Ronald Gaddie, and Brad Lickerbie. "The Electoral Consequences of Voting to Declare War." The Journal of Conflict Resolution 39(1995): 172.

${ }^{3}$ See Note 1
} 
and House of Representatives of the United States of America in Congress assembled, That the state of war between the United States and the Imperial Government of Japan which has thus been thrust upon the United States is hereby formally declared; and the President is hereby authorized and directed to employ the entire naval and military forces of the United States and the resources of the Government to carry on war against the Imperial Government of Japan; and, to bring the conflict to a successful termination, all of the resources of the country are hereby pledged by the Congress of the United States. Approved, December 8, 1941, 4:10 p.m. E.S.T." (SJR 116 1941)

The pattern, which was laid out by the War of 1812 declaration, held consistent overtime with each of the major declaration first recognizing that a state of war exists, and then delegating to the president all power to prosecute the war, including those powers delegated to congress by the constitution.

Of course the use of force by the United States has not been limited simply to the six wars mentioned here, and indeed many of the major conflicts of the 20th century simply do not appear on this list and it seems unlikely that they simply prosecuted with no congressional discussion or action. Often the use of force is authorized by a resolution authorizing that force rather than a formal declaration of war. Congress has historically provided these authorizations much like they have granted declarations of war; at the behest of the President and after hostilities already exist. It is instructive to observe the list in some detail as it spans from $1798-2002$ with a variety of circumstances and incidents. The authorization of force in this manner merits unique consideration as it is fundamentally different from a declaration of war in that, as it is not a uniquely held congressional power the joint resolution authorizing force is signed by the President under the normal legislative procedures, and therefore is not solely a congressional act.

Table 2. Authorizations of Force by Congressional Act ${ }^{4}$

\begin{tabular}{|c|c|c|}
\hline Date & Nations Involved & Circumstance \\
\hline May 28,1798 & France & $\begin{array}{c}\text { Protection of US ships against } \\
\text { seizure }\end{array}$ \\
\hline December 8, 1801 & Tripoli & $\begin{array}{c}\text { Protection of US ships against } \\
\text { Piracy }\end{array}$ \\
\hline March 3, 1815 & Algeria & $\begin{array}{c}\text { Protection of US ships against } \\
\text { seizure }\end{array}$ \\
\hline March 3, 1819 & No Nation, All Pirates & Protection of Vessels from Piracy \\
\hline January 24,1955 & China, Formosa, Pescadores & $\begin{array}{c}\text { Protection of Formosa \& } \\
\text { Pescadores from Chinese Attack }\end{array}$ \\
\hline March 9, 1957 & Middle East & $\begin{array}{l}\text { To deal with possibility of } \\
\text { communist aggression }\end{array}$ \\
\hline August 5, 1964 & Vietnam & $\begin{array}{l}\text { Golf of Tonkin Resolution, to } \\
\text { fulfill SEATO treaty. }\end{array}$ \\
\hline October 12,1983 & Lebanon & $\begin{array}{l}\text { Allow Marines to remain in } \\
\text { Lebanon for } 18 \text { months. }\end{array}$ \\
\hline January 12, 1991 & $\mathrm{Iraq}^{5}$ & Enforcement of Un Resolution \\
\hline September 18, 2001 & Terrorist nations ${ }^{6}$ & $\begin{array}{l}\text { To use force against those who } \\
\text { participated in the } 9 / 11 \text { attacks }\end{array}$ \\
\hline October 16, 2002 & Iraq & $\begin{array}{l}\text { Authorization of the use of force } \\
\text { against Iraq. }\end{array}$ \\
\hline
\end{tabular}

\footnotetext{
${ }^{4}$ Adapted from: Elsea, Jennifer and Richard Grimmett. "Declarations of War and Authorizations for the Use of Military Force: Historical Background and Legal Implications." CRS Report for Congress 11 Aug 2006 6-22. 28 Oct 2006.

5 See Note 2

${ }^{6}$ This resolution was used to invade Afghanistan, and currently is touted as remaining in effect to hunt down terrorist wherever they may be.
} 
Again in each instance listed congressional action was in response to a request from the President to utilize force. Nearly every use of the congressional war power has been predicated on the desire of the executive to utilize the war powers granted him under the Constitution. Simply answering the desires of the executive is not the established constitutional order. That there are times when it is appropriate for the President to ask congress for the use of war power is not argued here. Rather it is argued that one would expect under the constitutionally mandated system Congress would undertake its war power independently from time to time.

This is not to say that there haven't been attempts by congress from time to time to exercise control of the use of War Power. These attempts have mostly tried to force the President to avoid committing troops to hostile areas without the approval of Congress. Congress has seemed to desire mostly to be consulted and to give approval to actions the executive wants to undertake. The roots of this power are found in the informal oversight authorities provided by the constitution to congress through budgetary, regulatory, and impeachment powers. Frederick Kaiser writes that, “... the necessary and proper clause allows Congress to pass laws that mandate oversight, grant relevant authority to itself and its support agencies, and impose specific obligations on the executive branch, such as reporting or consultation requirements." This conception of congressional oversight has been the chief form by which attempts to curtail executive war power expansion has occurred. Congress has not declared any war, or utilized the other powers listed in Article 1Section 8 outside a request from the President. They have instead attempted to assert power in one primary way through the post Vietnam war, the War Powers Resolution.

\subsection{The War Powers Resolution}

The War Powers Resolution was a direct response to both the Vietnam conflict and ever growing concerns about executive power in the post Watergate era. It attempted to create parameters under which Presidents could use military force and the manner in which congress would authorize it. The act, which has been denounced by many as unconstitutional, has yet to see its day before the Supreme Court and remains law as no President or Congress has chosen to attempt to push a challenge to the act to the Supree Court. Presidents have traditionally refused to recognize the act as binding and Congress's have refused to push the issue to a final resolution. The act has therefore been rendered essentially toothless until some future congress chooses to enforce its provisions.

The purpose of the act as described in the resolution it self is , "It is the purpose of this joint resolution to fulfill the intent of the framers of the Constitution of the United States to insure that the collective judgment of both the Congress and the President will apply to the Introduction of the United States Armed Forces into hostilities, or into situations where imminent involvement in hostilities is clearly indicate by the circumstances, and to the continued use of such forces in hostilities or in such situations." That the ends are noble is certainly not disputable, however the resolution introduced highly controversial requirements that have been much discussed in the years since passage.

The Specific Provisions of the Resolution have been much discussed, and are relatively straight forward, although a plethora of Presidents have managed to either willfully or through ignorance managed to avoid the intent of the act by refusing to utilize the specific provisions. 
Table 3. Provisions of the War Powers Resolution (War Powers Resoultion 1973)

\begin{tabular}{|c|c|}
\hline Section & Requirement \\
\hline 2.C & The President May Only Introduce Armed Forces Into Hostilities If: \\
\hline & $\begin{array}{l}\text { 1. A declaration of war has been made, } 2 \text {. Specific statutory authorization has been } \\
\text { granted, 3. A national emergency created by attack on the United States has occurred }\end{array}$ \\
\hline 4.A & $\begin{array}{l}\text { The President Must Notify Congress within } 48 \text { hours absent a declaration of war of any } \\
\text { case where US armed forces are introduced into either imminent or actual hostilities, } \\
\text { into foreign nations while equipped for combat, in numbers substantially higher than } \\
\text { current levels in a given country. }\end{array}$ \\
\hline 4.A.1.A & $\begin{array}{c}\text { The Report Must Include: The circumstances necessitating their use, the constitutional } \\
\text { and legislative authority under which the troops were deployed, the estimated scope } \\
\text { and duration of the involvement. }\end{array}$ \\
\hline 4.A.1.B & $\begin{array}{l}\text { The President must provide other information as Congress requests to fulfill its } \\
\text { constitutional duties. }\end{array}$ \\
\hline 4.A.1.C & $\begin{array}{l}\text { While engaged in hostilities under this act the President must report to congress often } \\
\text { and no less than once every six months. }\end{array}$ \\
\hline 5.A. & Congress must consider the report of the President \\
\hline 5.B & $\begin{array}{l}\text { Within Sixty days after a report is submitted or is required to be submitted the President } \\
\text { must terminate use of troops unless; War has been declared, and extension has been } \\
\text { granted, if physically unable due to unavoidable military necessity surrounding the } \\
\text { safety of troops. }\end{array}$ \\
\hline $5 . \mathrm{C}$ & $\begin{array}{l}\text { Despite the provisions of this resolution, the President must remove troops at any time } \\
\text { upon receipt of a concurrent resolution directing that action. }\end{array}$ \\
\hline
\end{tabular}

In only one case has a report been submitted pursuant to Section 4.A.1, by President Ford in the Mayaguez capture, which had little effect as the report was released only after the operation was completed, and therefore no real congressional oversight was possible. (Fisher and Alder 1998)

In his veto message ${ }^{7}$ which accompanied the resolution back to Congress, President Nixon denounced the act as unconstitutional, a position which every President since has maintained. However, with the clear responsibility of Congress to Declare war, those who which to declare it unconstitutional must as Stephen Carter states; "be prepared to explain the purpose of Article I, Section 8 Clause 11, of the constitution. That provision expressly grants to the Congress the power 'declare war'. If the President of the United States is free to fight a war whether or not one has been declared, then this apparently unambiguous constitutional provision is devoid of significance."

The questions of constitutionality would be moot if there had not been military actions which would be governed by the act since its inception. The history reveals that there are many. The Table which follows illustrates the times when actions have occurred that would qualify under the War Powers Resolution and Presidential actions with regard to the requirements of the Resolution.

\footnotetext{
${ }^{7}$ A veto that was overridden by Congress.
} 
Table 4. Major Conflicts after the War Powers Resolution 1973-1995

\begin{tabular}{|c|c|c|c|}
\hline Case & Initiation Date & Duration & Congressional Actions \\
\hline Cyprus & July 1974 & 2 Days & None \\
\hline Dananag & 5 April 19/75 & $31 / 2$ Weeks & None \\
\hline South Vietnam & 29 April 1975 & 1 Day & None \\
\hline Mayaguez Incident & 13 May 1975 & 2 Days & None \\
\hline Iran & 24 April 1980 & 1 Day & None \\
\hline Gulf of Sidra, Libya & 19 August 1981 & 1 Day & None \\
\hline Lebanon & 25 August 1982 & $31 / 2$ Weeks & None \\
\hline Lebanon & 19 September 1982 & 18 Months & $\begin{array}{l}\text { House Passed Resoluton } \\
\text { authorizing Marine } \\
\text { Placement avoiding } \\
\text { Supreme Court Fight }\end{array}$ \\
\hline Grenada & 25 October 1983 & 1 Month & $\begin{array}{l}\text { House Passed HJR402 } \\
\text { indicating they were } \\
\text { starting the War Powers } \\
\text { Clock. Senate declined } \\
\text { ot ask. }\end{array}$ \\
\hline Libya & 23 March 1986 & 3 Weeks & None \\
\hline Persian Gulf & 17 May 1987 & 16 Months & $\begin{array}{l}\text { Congress demanded } \\
\text { reports consistent with } \\
\text { the act and some } \\
\text { Members of congress } \\
\text { demanded }\end{array}$ \\
\hline Panama & 20 December 1989 & 1 Week & None \\
\hline Kuwait (Desert Shield) & 28 August 1990 & 4 Montsh & $\begin{array}{l}\text { None until escalation } \\
\text { and then hearings held. }\end{array}$ \\
\hline Somalia & 2 December 1992 & 15 Months & $\begin{array}{l}\text { Conflict between } \\
\text { Congress and President } \\
\text { resolved when troops } \\
\text { removed one day prior to } \\
\text { Congressional } \\
\text { Resoluiton. }\end{array}$ \\
\hline
\end{tabular}

The refusal of Presidents to submit reports pursuant to the specific section of the War Powers act has not however prevented them from attempting to placate Congress with reports they describe as being consistent with the War Powers Resolution, without either starting the sixty-day clock or recognizing the constitutionality of the resolution itself. The interesting game of chess that has surrounded the War Powers Resolution has done little to settle the question of how the War Powers reserved to congress should be utilized, and have in fact served to increase Presidential Prerogative to commit US troops by giving care blanche to sixty-day operations without congressional approval.

\footnotetext{
${ }^{8}$ Information Adapted from: Auerswald, David, and Peter Cowhey. "Ballot box Diplomacy: The War Powers Resolution and the Use of Force." International Studies Quarterly 41(1997): 505-528. Page 521.
} 


\section{Reasserting Congressional Power?}

As such the history of the War Powers Resolution is suspect as to its ability to reassert Congressional War Powers. One of the core constitutional issues, which have troubled many about the Resolution itself, is that it may contain a congressional veto, which has been banned by the Supreme Court.

Within the War Powers Resolution is a provision under which congress can direct the president by concurrent resolution to remove troops from any theatre of hostility. The order of either a single house of congress or both acting under a concurrent resolution to force executive action was invalidated by INS V. CHADHA. The case stated that the use of a legislative veto was a violation of the presentment clause, which requires that all legislation be presented to the President for his affirmation or veto. The case for the constitutionality of the War Powers Resolution's provision which has been called a legislative veto is not invalidated by the above case.

Stephen Carter asserts that, "The War Powers Resolution is constitutional because its terms constitute a congressional definition of the word 'war' as it is used in article I." The distinction essentially is that the unconstitutional legislative veto is creating new law, and the War Powers Resolution is merely defining and asserting a Congressional power that has neither been delegated nor belongs to any other branch. As such Congressional War Powers should be able to direct the President when war is permissible.

A second school asserts that most of the conflicts where war has not been declared have not really been wars, but rather some other type of military conflicts which would exist under the purview of the commander-in-chief to prosecute without congressional authorization. This assertion is based in simple tradition, that this has in fact occurred. The question of these more limited engagements were considered as early as 1800 when in Bas v. Tingey, "The Court held that it is for Congress alone to authorize either an 'imperfect' (limited) war or a 'perfect' (declared) war." Fisher furthers clarifies citing Talbot V. Seeman, "A year later, the Court stated with great clarity: 'The whole powers of war, being by the constitution of the United States, vested in congress, the acts of that body alone can be resorted to as our guides in the enquiry."(Fisher and Alder 1998) Clearly regardless of size military actions involving hostilities require congressional oversight and authorization. As such the constitutionality of the War Powers Resolution is affirmed.

The far bigger question is whether it has or could reassert Congressional War Power. As has been described above the reality is that the President may now with full permission of Congress enter into hostilities for 60 days and most likely 90 days with out congressional permission. As such the War Powers Resolution has been a mixed bag. While it forces interaction between the President and Congress on matters of war it has done little to promote the actual use of War Power by Congress, and has instead facilitated the delegation of that power by setting time frames under which permission is not needed. Louis Fisher sums up the Resolution, "In fact, it [The War Powers Resolution] was ill conceived and badly compromised form the start, replete with tortured ambiguity and self-contradiction. The net result was to legalize a scope for independent presidential power that would have astonished the Framers..."(Fisher and Alder 1998)

The reality of the failure of Congress to effectively utilize the war powers that the constitution delegates to it is well proved by the litany of examples both cited here and in further reading on the subject. Why then has congress been so reluctant, or perhaps unable to utilize the delegate powers. The failure of Congress in this regard is not an innovation of the 20th century. The roots of the problem are found in the very nature of the legislative body, and the necessity of reelection.

The questions of war and peace are almost always of such a time sensitive nature that the ability of legislative bodies to effectively deal with the intricacies of them is nearly impossible. It is in this deliberative structure that the reason for Presidential requests for Declarations of War, Authorizations of Force, and independent actions are found. The framers considered the tensions between swift action and deliberative consideration as they drafted the constitution. Indeed from this very concern came the Presidential ability to take military actions when the US was attacked or invaded with out congressional declaration of war, and why the first draft of the constitution was altered to give Congress the power to "declare war" rather than the much more expansive "make war" The recent "War on Terror" delivered a near daily discussion of supporting the President from members of congress, and very little discussion of increasing the role Congress should play with relation to the war. In fact, Congress sanctioned the war on terror with all of its ambiguity with no specific enemy, no time line, and no real objectives. There seems to be no potential action that couldn't be construed to fit under this authorization of force.

Even more important to the ebb of congressional war power than the deliberative nature of the institution, is the political realities of reelection, and the potential political liability of utilizing the War Power. These political liabilities come from members being forced to vote for or against potential military actions, and then live with the 
consequences of those votes. As such many members of Congress are content to allow the "commander-in-chief" to bear full responsibility for the military action, and to make him responsible for the action.

The motivation of members of congress to avoid being seen as questioning the use of the United States military emerges from the "rally around the flag effect" used by Regens to explain why Congress members are so hesitant to vote against war measures. He identifies the effect as, "a president facing a foreign policy crisis is able to invoke national interest in support of his policy during the crisis in the manner Sigelman and Conover described as capitalizing on "threats from outside a system [that] promote cohesion inside the system."(Regens 1995) In short the good will generated by the necessity of Military Action may serve to undermine those who do not support the action. The flip side of the coin however is the "costs of war hypothesis", which essentially asserts that as armed conflict continues the costs of war will result in growing dissatisfaction with the party in power who instigated the now costly military action. The sum of both these hypotheses drive members of congress to distance themselves as far as possible from the use of the War Powers. They instead wish to be supportive when the national opinion supports war and skeptical when the opinion is one of disaproval. This desire is clearly illustrated by the desire of nearly all members of congress to provide both the power and responsibility for the recent Iraq war to the President. Congress appeared to want to avoid the potential problems that come from the use of the war powers, and yet to still have those powers used when the perception was that they were necessary. As such it has abrogated its power to the executive branch in practice, if not in total. The irony of this perceived reality is that an empirical study by James L. Regens essentially negates the conventional wisdom in modern elections, those who vote against military action are no more likely to be defeated than those who do not. However as always politics is not necessarily a question of reality but is rather one of perception.

It is certainly understandable from the point of view of individual members of Congress that they would be reluctant to utilize War Powers in the form originally intended by the Framers. However, the perceptions, which dictate the concern for reelection, are phantoms of rumor and lack substance when empirically evaluated.

The situation certainly seems dire for the continued existence of Congressional War Power, or at least Congress's willingness to utilize those powers. The prescription to reassert these powers is relatively simple in its requirements and politically and administratively complex in its implementation. In short Congress must demand, and enforce its demands to supervise the War Powers, with both the benefits and costs of doing so, if it is ever to reclaim them from the executive branch.

\section{References}

"An Act Declaring that war exists between the United States of America and the Kingdom of Spain" Ch 189, 30 Stat. $364 . \quad$ Retrieved from https://www.history.navy.mil/research/library/online-reading-room/title-list-alphabetically/d/declarations-w ar-authorizations-use-military-force.html\#a1

An Act Declaring War Between the United Kingdom of Great Britain and Ireland and the Dependencies thereof and the United States of America and Their Territories. (1812). Retrieved from http://avalon.law.yale.edu/19th_century/1812-01.asp

Auerswald, D., \& Cowhey, P. (1997). Ballot box Diplomacy: The War Powers Resolution and the Use of Force. International Studies Quarterly, 41, 505-528. http://dx.doi.org/10.1111/0020-8833.00054

Declaration of The State of War with Japan S.J.Res. 116. Retrieved from http://avalon.law.yale.edu/wwii/dec04.asp\#japan

Elsea, J., \& Grimmett, R. (2006). Declarations of War and Authorizations for the Use of Military Force: Historical Background and Legal Implications. CRS Report for Congress 11 Aug 2006 6-22. 28 Oct 2006.

Fisher, L., \& Alder, D. (1998). The War Powers Resolution: Time to Say Goodbye. Political Science Quarterly, 113, 1-20. http://dx.doi.org/10.2307/2657648

Gelpi, C., Feaver Peter, D., \& Reifler, J. (2005). Success Matters: Casualty Sensitivity and the War in Iraq. International Security, 30, 7-46. http://dx.doi.org/10.1162/016228805775969573

INS v. CHADHA. 462 U.S. 919. U.S. Sup. Ct. 1983. Page 4

Jefferson, Thomas. Letter to James Madison 6 Sept. 1789.

Kaiser, Frederick. "Congressional Oversight of the Presidency." Annals of the American Academy of Political and Social Science 499Sep 198877.

Ketchum, R. (Ed.). (1986). The Ant-Federalist Papers and the Constitutional Convention Debates. New York: 
Mentor, P. 138.

Lee, R. A. (1999). The History Guy: U.S. Declaration of War Against Japan (1941). Retrieved from http://www.historyguy.com/us_dec_war_japan.html

Presidential Messages and State Papers, Vol. III, New York: The Review of Reviews Company. (1917). Retrieved from http://www.spanamwar.com/McKinleywardec.htm

Regens, J., Gaddie, R., \& Lickerbie, B. (1995). The Electoral Consequences of Voting to Declare War. The Journal of Conflict Resolution, 39, 172. http://dx.doi.org/10.1177/0022002795039001007

Rossiter, C., \& Kesler, C. (Eds.). (Eds.). (1999). The Federalist Papers. New York: Mentor. P. 415.

US Constitution, Article 1 Section 8.

War Powers Resolution. Pub. L. 93-148. 07 Nov. 1973. H.J Res. 542.

\section{Notes}

Note 1. Much discussion exists between where to classify this action, I have included it here as the wording of the authorization seems to reasonably indicate war was declared but it could also be classified as an authorization of force resolution.

Note 2. See Note 1.

Note 3. This resolution was used to invade Afghanistan, and currently is touted as remaining in effect to hunt down terrorist wherever they may be.

Note 4. A veto that was overridden by Congress.

\section{Copyrights}

Copyright for this article is retained by the author(s), with first publication rights granted to the journal.

This is an open-access article distributed under the terms and conditions of the Creative Commons Attribution license (http://creativecommons.org/licenses/by/4.0/). 